urnal Ilmiah Teunuleh

The International Journal of Social Sciences

Vol. 2, Issue. 1, Mar 2021

E-ISSN: 2746-4393

\title{
THE EFFECT OF HOUSEHOLD WASTE MANAGEMENT ON FLOOD PREVENTION IN BEKASI REGENCY
}

\author{
Marningot Tua Natalis Situmorang \\ Department of Environmental Engineering, Faculty of Engineering, Universitas Sahid, Indonesia \\ uchoxs@yahoo.com
}

\begin{abstract}
This research was conducted on housewives whose houses were affected by the flood on January 1, 2020 in Bekasi Regency. The selection of respondents using purposive sampling with simple random sampling on 5 (five) housing in Bekasi Regency which was affected by the flood disaster. The research sample was 120 people, which consisted of the direct behavior category and indirect behavior. These two categories were identified after socialization on waste and household waste management was carried out. Based on statistical tests, there is a partially significant influence between knowledge of waste management on people's behavior in managing household waste. The results of statistical tests also show that there is a partially significant influence between attitudes about waste management on waste management behavior. In addition, the statistical test results show that there is a simultaneous significant influence between knowledge and attitudes about waste management on the behavior of Bekasi Regency residents managing household waste to cope with flooding. From the results of this study, it can be concluded that the majority of Bekasi Regency residents have good knowledge, attitudes and behavior towards household waste management such as not littering and not burning garbage. The results also found that household waste was not the main cause of flooding in Bekasi Regency.
\end{abstract}

Keywords: Knowledge, Attitudes, Behavior, Household Waste Management, Flood Prevention

\section{A. Introduction}

The development of cities in developing countries, especially in Indonesia, raises many development problems. Starting from the increasing urbanization problem, the problem of slum settlements and resulting in poor sanitation, transportation problems, clean water problems to urban waste problems as a result of population activities 
(Darmawan, 2014). Human behavior that is not responsible for waste can cause problems and environmental damage. If human behavior is more directed towards personal interests, and less or does not consider public interests, it can be predicted that the carrying capacity of the natural environment will be increasingly depleted and as a result environmental losses and damage cannot be avoided (Wibowo, 2009).

Garbage that has accumulated will be dangerous and can be in the form of materials contaminated with dioxins and heavy metals, such as mercury, cadmium, lead, or organic waste from industrial activities. This waste comes in various forms ranging from sludge liquid waste barrels, old computer parts, used batteries, or incinerator ash ( (Olowu, 2012).

Garbage is a serious problem for people, especially in urban areas. So far, people just throw garbage into the trash cans and leave the next matter to the janitor and the business is over, but actually the problem doesn't end there. Garbage piles in landfills become a separate problem, a problem of health, pollution and environmental beauty (Mifbakhuddin, Salawati, \& Kasmudi, 2010).

The landfill of waste continues to increase with population growth, not only in terms of quantity, but the quality or composition of waste is also increasingly complex, as a result of changes in people's lifestyles and economic growth. The volume of waste generation will also cause many problems in various aspects of life, both from an environmental, social and economic perspective. An environmental problem that often arises is the accumulation of garbage in collection locations (Maulina, 2012).

Data from the Office of the Ministry of Environment states that, with the amount of waste produced in every region of Indonesia, the average waste production reaches 300 tons per day.

In Bekasi Regency, especially in areas adjacent to the banks of the Citarum River, Cibeet River, Cipamingkis River, and several other rivers and their tributaries such as Grand Mutiara Gading Housing, Griya Mustika Media Housing, Puri Asri Indah Housing, Griya Setu Permai Housing and Housing Griya Bekasi Permai, there are still many areas that should be used as water catchment areas and flood retardants but instead are used as settlements, and disposal of household waste, as well as drainage channels which should function to drain wastewater into an alternative place for garbage disposal, so that it is not uncommon for this area to experience flood problems, especially when the rainy season arrives. 
Starting from this problem, residents in Bekasi Regency should be able to learn to care about the cleanliness of the environment around where they live, and have the willingness to take positive action to improve the quality of the environment that has decreased due to the problem of household waste, besides that residents also need to develop a system. Independent and productive community-based waste management with the $3 \mathrm{R}$ principle (Reduce, Reuse, Recycle) with the aim of reducing the volume of household waste produced while increasing the added value of the waste, so that it can provide benefits to the community, both directly and indirectly (Aryenti, 2012).

Based on the fact that floods still hit most areas of Bekasi Regency when the rainfall was high, it is necessary to study how to handle household waste of Bekasi Regency residents. It is necessary to investigate what factors cause this to happen, so that knowing these factors is expected to make it easier to find and determine the most appropriate and effective solution to overcome it (Slamet, 2012). According to Notoatmodjo (2010), a person's behavior is closely related to the level of knowledge and how the person's attitude towards something, so in this context to find out this relationship it is necessary to examine how the influence of knowledge and attitudes of Bekasi Regency residents regarding waste management on their behavior in managing household waste stairs resulting in flooding.

\section{B. Research Method}

This research will be carried out on housewives who were affected by the flood on January 1, 2020, in several housing complexes in the Bekasi Regency area for three months, from early March 2020 to early June 2020 with an allocation of activity time according to the schedule.

The target population in this study were housewives whose houses were affected by flooding in Bekasi Regency. Meanwhile, the affordable population (the sample) is 120 people. The sampling was carried out by purposive random sampling technique, namely unit sampling, not based on individuals, but based on groups of individuals residing in the housing (group sample) by means of random sampling, thus obtaining 5 groups, namely group I Grand Mutiara Gading Housing, group II Griya Mustika Media Housing, group III Puri Asri Indah Housing, group IV Griya Setu Permai Housing and group V Griya Bekasi Permai Housing. Each selected housewife participated in the socialization and practice of household waste management. 
Data collection in this study includes data on the behavior of managing household waste $(Y)$, knowledge and attitudes about managing household waste $(X)$. Data regarding the behavior of managing household waste $(Y)$, the scoring consists of five options, with scoring techniques in the form of: for good answers given a score of 3 (three), it is enough to give a score of 2 (two), and less to give a score of 1 (one).

For the score of knowledge about managing household waste, the correct answer is given a score of 1 (one), and for the wrong answer is given a score of 0 (zero). Furthermore, the feasibility of the items used in the knowledge and attitude test about managing household waste was determined based on the results of the item analysis in the form of validity and reliability testing.

The data analysis technique used multiple linear regression, $t$ test, and $F$ test with SPSS software to test the effect of partially and simultaneously on the research variables.

\section{Finding and Discussion}

From field observations, it is known that most Bekasi Regency residents have started implementing household waste management with the $3 \mathrm{R}$ principle (Reduce, Reuse, and Recycle) such as sorting between organic and non-organic waste, this is possible because most residents are still already have knowledge about good household waste management, environmentally friendly and provide added value to the waste itself. To determine the level of knowledge of Bekasi Regency residents about household waste management, this research was conducted to collect data related to residents' knowledge about waste management. The results of data collection and processing are presented in table 1 below:

Table 1. Category of Waste Management for Residents of Bekasi Regency, West Java

\begin{tabular}{llllll}
\hline & & & Valid & Cumulative \\
& & Frequency & Percent & Percent & $\begin{array}{c}\text { Persent } \\
\text { Valid }\end{array}$ \\
& Kurang & 26 & 21.7 & 21.7 & 21.7 \\
& Cukup & 35 & 29.1 & 29.1 & 50.8 \\
& Baik & 59 & 49.2 & 49.2 & 100.0 \\
& Total & 120 & 100.0 & 100.0 & \\
\hline
\end{tabular}

Source: Processed field data (primary data)

Based on the data from Table 1 it can be explained that of the 120 people who were sampled in this study, there were 26 people or $21.7 \%$ of respondents who still lacked knowledge of waste management; $29.1 \%$ of respondents have sufficient knowledge, and $49.2 \%$ have good knowledge. This means that many respondents have 
knowledge of good household waste management to deal with floods. However, floods still frequently hit their housing camps. This may be due to the condition of the river that is not deep enough or the embankment that is still unable to withstand the water discharge when the rainfall is high. In addition to knowledge about waste management, a person's attitude towards waste management is thought to have an effect on waste management behavior so that it can reduce flooding. The more positive a person's attitude about waste management, usually his behavior in managing waste will also be better, and vice versa (Puspitawati \& Rahdriawan, 2012). Attitudes have a role in human behavior patterns which are views or feelings accompanied by a tendency to act on a certain thing or object (Walgito, 2006). This attitude can be positive and it can also be negative. In a positive attitude, the tendency to stay away, avoid, hate, and dislike certain objects. A person's attitude towards an object is a feeling of support or favor (favorable) or a feeling of not supporting or not taking sides (unfavorable) on the object (Azwar, 2008).

Associated with the description above, what is meant by the attitude in this research is that the attitude about waste is associated with independent waste management by the community with indicators including: landfill, the relationship between waste and health, how to manage waste, feelings of like or dislike in management. Independent waste, forced or not forced, difficulty and ease of fulfilling the need for equipment for independent waste management, and efforts that are being and will be made to fulfill independent waste management. To find out how the attitude of the residents of Sewu Village about waste management, data collection was carried out related to residents' attitudes about household waste management. The results of data collection and processing are presented in table 2 below:

Table 2 Category of Solid Waste Management Attitudes for Residents of Bekasi Regency, West Java

\begin{tabular}{llllll}
\hline & & Frequency & Percent & \multicolumn{1}{c}{$\begin{array}{c}\text { Valid } \\
\text { Percent }\end{array}$} & \multicolumn{1}{c}{$\begin{array}{c}\text { Cumulative } \\
\text { Persent }\end{array}$} \\
\hline Valid & Less & 30 & 25 & 25 & 25 \\
& Enough & 37 & 30.8 & 30.8 & 55.8 \\
& Good & 53 & 44.2 & 44.2 & 100.0 \\
& Total & 120 & 100.0 & 100.0 & \\
\hline
\end{tabular}

Source: Processed field data (primary data)

Based on the data from table 2, the results of the attitude research conducted on 120 people were 53 people or $44.2 \%$ of respondents had a good attitude towards 
household waste management, which means that only a few respondents had a negative attitude towards waste management. This happens because respondents are residents of elite housing and the majority are highly educated, and have a good working environment, so they think that waste management is important, this is the main reason Bekasi Regency residents like to manage the waste they produce. Apart from the knowledge and attitudes of residents about waste management, data collection and processing were also carried out to find out how the behavior of Bekasi Regency residents in managing their daily household waste. The results of data processing on the behavior of residents in managing waste are presented in table 3.

Table 3 Categories of Waste Management Behavior for Residents of Bekasi Regency, West Java

\begin{tabular}{llllll}
\hline & & Frequency & Percent & Percent & $\begin{array}{c}\text { Cumulative } \\
\text { Persent }\end{array}$ \\
\hline Valid & Less & 18 & 15 & 15 & 15 \\
& Enough & 40 & 33.3 & 33.3 & 48.3 \\
& Good & 62 & 51.7 & 51.7 & 100.0 \\
& Total & 120 & 100.0 & 100.0 & \\
& & &
\end{tabular}

Source: Processed field data (primary data)

From table 3, it shows that there are 18 people or $15 \%$ of respondents who have a bad attitude towards the household waste they produce, such as throwing garbage into rivers, gutters, and burning the waste they produce. This is one of the causes of environmental problems in this area, but the impact is not too significant for flooding in the Bekasi district.

In general, from the data above, it can be explained that the respondents' knowledge about waste management is good, as well as their attitudes and behaviors. The relationship between knowledge and behavior and the relationship between attitude and behavior is presented in table 4 below:

Table 4: Partial t-test results for knowledge variables and attitudes towards behaviour Coefficients $^{a}$

\begin{tabular}{|c|c|c|c|c|c|c|}
\hline \multirow[b]{2}{*}{ Model } & & $\begin{array}{c}\text { Unstandardized } \\
\text { Coefficients }\end{array}$ & & $\begin{array}{l}\text { Standardized } \\
\text { Coefficients }\end{array}$ & \multirow[b]{2}{*}{$\mathrm{t}$} & \multirow[b]{2}{*}{ Sig. } \\
\hline & & B & Std. Error & Beta & & \\
\hline \multirow[t]{3}{*}{1} & (Constant) & 5.678 & .532 & & 11.456 & .000 \\
\hline & Knowledge & .317 & .014 & .521 & 11.552 & .000 \\
\hline & Attitude & .113 & .013 & .336 & 10.987 & .000 \\
\hline
\end{tabular}


a. Dependent Variable: Behavior

Source: Data processed (2020)

Based on table 4, there are two important things, namely how the partial influence of the knowledge variable about waste management on waste management behavior, and how partially the influence of attitude variables about waste management on waste management behavior is as follows:

a. Partial Influence of Knowledge Variables on Behavior

The influence of knowledge about waste management on the behavior of managing waste based on the results of the regression test $t$ count 11,552 is statistically significant ( $p$ <.05), meaning that there is a partially significant influence between the knowledge variable about waste management on the behavior of respondents in managing household waste. Respondents' knowledge of good and environmentally friendly waste management has resulted in good behavior towards the household waste they produce.

The community's knowledge about household waste management is influenced by how much information about how and the benefits of managing waste are obtained. Most residents in Bekasi Regency have received information in the form of socialization and counseling on good and environmentally friendly waste management, so that their knowledge of the ways and benefits of carrying out waste management is also very good. This is what causes the high knowledge of most Bekasi Regency residents about the ways and benefits of managing household waste.

A person's knowledge is influenced by several factors such as education, information and culture (Notoatmodjo, 2010). From the educational aspect, the higher a person's education level, the easier it will be to accept new things so that it will be easier to complete new things (Slamet, 2012)

b. Partial Influence of Attitude Variables on Behavior

The results of the research on attitudes about waste management on the behavior of residents managing waste in Bekasi Regency, obtained a significant positive t count ( $p$ $<0.05$ ) which indicates a positive influence between attitudes about waste management on household waste management behavior. Most residents in Bekasi Regency have played an active role in managing household waste, residents perceive that waste management is important to prevent floods and other environmental pollution, and waste management is considered not only a matter for cleaning officers to be the main reason residents manage the household waste they produce. . This is one of the reasons 
for the good behavior of most residents towards garbage, such as not littering on roadsides, gutters, rivers, and bushes, and not burning the resulting trash. Burning garbage is an alternative to eliminating waste which can actually cause air pollution and respiratory problems.

The effect of the independent variables (knowledge and attitudes about waste management) on the dependent variable (the behavior of residents managing waste) simultaneously (together) can be seen from the results of multiple regression testing which are presented in table 5.

Table 5. Simultaneous F-Test Results for Knowledge and Attitude Variables on ANOVA ${ }^{2}$ Behavior

\begin{tabular}{llrrrrr}
\hline \hline Model & & Sum of Squares & df & Mean Square & F & Sig. \\
\hline 1 & Regression & 499.271 & 2 & 249.635 & 129.247 & $.000^{\mathrm{b}}$ \\
& Residual & 662.490 & 343 & 1.931 & & \\
& Total & 1161.760 & 345 & & & \\
\hline \hline
\end{tabular}

a. Dependent Variable: Behavior

b. Predictors: (Constant), attitude, knowledge

The results of testing the simultaneous influence of the knowledge and attitude variables on behavior in Table 5 show that knowledge and attitudes have an effect on behavior. This can be seen from the value of $F$ count $=129.247$ with $p$ value $<0.05$, which means that there is a significant influence simultaneously (together) between knowledge and attitudes about waste management on the behavior of residents managing household waste.

\section{Conclusion}

Based on the results of this study it can be concluded the following:

a. Most residents of Bekasi Regency have good knowledge, attitudes, and behavior towards household waste management, such as not littering and not burning garbage.

b. It is not household waste that is the main cause of flooding.

c. There is a partially significant influence between knowledge about waste management on the behavior of residents in managing household waste, from the results of the $t$ test obtained $p$ value $<0.05$. 
d. There is a partially significant influence between attitudes about waste management on waste management behavior, from the t test results obtained $p$ value $<0.05$.

e. Testing F count $=129.247$ with $p$ value $<0.05$. This shows that there is a significant influence simultaneously between knowledge and attitudes about waste management on the behavior of residents managing household waste.

\section{Suggestion}

a. Even though Bekasi Regency residents have good knowledge, attitudes and behavior towards household waste management, there is still a need for community education and out-of-school education programs on independent and productive community-based waste management with the $3 \mathrm{R}$ principles (Reduce, Reuse, and Recycle) continuously in Bekasi District to maintain the attitudes and behavior of residents about the ways and benefits of managing household waste. If residents understand the benefits or advantages of carrying out waste management, it is hoped that it can foster a positive attitude towards waste management so that their behavior in managing waste is expected to be even better in the future. This can be done by the government and community organizations such as non-governmental organizations (NGOs), universities and others.

b. Providing adequate waste management facilities and infrastructure that can be accessed by all residents of Bekasi Regency.

c. Encourage health workers and community leaders in Bekasi District to become good examples and role models for other regions.

d. Further research is expected to examine the main causes of flooding in the Bekasi Regency area, apart from household waste.

\section{Bibliography}

(BPS). (2018). Paparan Hasil Sensus Penduduk 2018. Kabupaten Bekasi, Propinsi Jawa Barat: Badan Pusat Statistik.

Arikunto, S. (2016). Prosedur Penelitian Suatu Pendekatan Praktek. Jakarta: Rineka Cipta. Aryenti. (2012). Peningkatan Partisipasi Masyarakat Dalam Pengelolaan Sampah Dengan Cara 3R (Reduce, Reuse, Recycle) di Kota Banjar. Jurnal Permukiman, 7(2), 101109. doi:10.31815/jp.2012.7.101-109 
Azwar. (2008). Sikap Manusia: Teori dan Pengukurannya. Jakarta: Pustaka Pelajar.

Ban, A. V., \& Hawkins, H. (2009). Penyuluh Pertanian. (A. D. Herdiasti, Trans.) Yogyakarta: Kanisius.

Bloom, B. S. (2004). Taxonomy of Education Objektives: The Clasification of Education Goals, Hand Book I, Cognitive Domain. New York: David McKay Company Inc.

Cahyono, B. (2013). Teknik dan Strategi Budidaya Pertanian. Jakarta: Yayasan Pustaka Nusatama.

Darmawan, A. (2014). Perilaku Masyarakat dalam Mengelola Sampah di Kota Bima Nusa Tenggara Barat. Jurnal Pembangunan Wilayah \& Kota, 10(2), 175-186.

Djumantri. (2007). Seni Mengelola Pekarangan. Jakarta : Departemen Pertanian.

Hjelle, L. A., \& Ziegler, D. J. (2012). Personality Theories; Basic Assumptions, Research and Application. New York: Mc Graw Hill, Inc.

Krech, D., \& Crutchfield, R. S. (2006). Elements of Psychology. New York: Alfred A. Knofp, Inc.

Mifbakhuddin, Salawati, T., \& Kasmudi, A. (2010). Gambaran Pengelolaan Sampah Rumah Tangga Tinjauan Aspek Pendidikan, Pengetahuan, dan Pendapatan Perkapita RT 6 RW 1 Kelurahan Pendurungan Tengah Semarang. Jurnal Kesehatan Masyarakat Indonesia, 6(1). doi:10.26714/jkmi.6.1.2010.\%25p

Nirwana, M. A. (2017). Pengaturan dan Strategi Penanggulangan Dampak Lingkungan Pencemaran Sampah Rumah Tangga di Bantaran Sungai Banjir Kanal Timur Kota Semarang. Semarang: Fakultas Hukum Universitas Diponegoro.

Notoatmodjo, S. (2010). Ilmu Kesehatan Masyarakat. Jakarta: Rineka Cipta.

Olowu, D. (2012). Menace Of E-Wastes In Developing Countries: An Agenda For Legal And Policy Responses. Law, Environment and Development Journal, 8(1), 59-75.

Pambudi, Y. S., \& Sudaryantiningsih, C. (2017). Analisis Pengaruh Pengetahuan dan Sikap Tentang Pengelolaan Sampah Terhadap Perilaku Warga dalam Mengelola Sampah Rumah Tangga di Kelurahan Sewu, Kecamatan Jebres, Kota Surakarta. Jurnal Kesehatan Kusuma Husada, 8(2), 101-108. doi:10.34035/jk.v8i2.226

Pertanian, D. (2008). Pedoman Pemilihan Metode Penyuluhan Pertanian. Jakarta: Pusat Penyuluhan Pertanian.

Puspitawati, Y., \& Rahdriawan, M. (2012). Kajian Pengelolaan Sampah Berbasis Masyarakat dengan Konsep 3R (Reduce, Reuse, Recycle) di Kelurahan Larangan 
The Effect of Household Waste Management on Flood Prevention in Bekasi Regency

Kota Cirebon. Jurnal Pembangunan Wilayah dan Kota, 8(4), 349-359. doi:10.14710/pwk.v8i4.6490

Rich, R. F. (2011). The Knowledge Cycle. London: Sage Publications Inc.

Romiszowski. (2009). Design Instructional Systems. London: Kagon Page.

Sarwono. (2012). Psikologi Lingkungan. Jakarta: Gramedia.

Slamet, Y. (2012). Konsep-Konsep Dasar Partisipasi Sosial. Yogyakarta: PAU UGM.

Soetomo, M. (2006). Mengelola Pekarangan Sejahtera. Bandung: Sinar Baru Algensindo.

Sudjana. (2016). Metode Statistika. Bandung : Tarsito.

Walgito, B. (2006). Psikologi Kelompok. Yogyakarta: Penerbit ANDI.

Wibowo, I. (2009). Pola Perilaku Kebersihan : Studi Psikologi Lingkungan Tentang Penanggulangan Sampah Perkotaan. Makara, Sosial Humaniora, 1, 37-47. 